$\Phi=5$

\title{
Role of bone morphogenetic proteins in periodontal regeneration- a review
}

\author{
Santhi Priya Potharaju ${ }^{1 *}$, Santha Kumari Prathypaty ${ }^{2}$, Ravi Kanth Chintala ${ }^{3 *}$ \\ Durga Bai Yendluri ${ }^{4}$, Jai Krishna Srikanth Kolliboyana ${ }^{5}$ * \\ ${ }^{1}$ Government Dental College \& Hospital \\ ${ }^{2}$ Government Dental College \& Hospital \\ ${ }^{3}$ Army Dental Corps \\ ${ }^{4}$ Government Dental College \& Hospital \\ ${ }^{5}$ Central Michigan University \\ *Corresponding author E-mail:drpriyatweety@gmail.com
}

\begin{abstract}
Bone Morphogenetic Proteins (BMPs) are multifunctional growth factors and have the unique property of inducing stem and mesenchymal cell differentiation in to osteogenic cells, capable of producing bone. They are categorized under the super family Transforming Growth Factor- $\beta$ (TGF- $\beta$ ). In the concept of tissue engineering they are the first approved therapeutic proteins to be used in conjunction with a scaffold and a biocompatible fixative device. Thus in this review the mechanism of action of BMPs is described at its cellular and molecular levels along with its potential clinical applications, utilization perspectives and scientific evidence in periodontal regeneration.
\end{abstract}

Keywords: Bone Morphogenetic Proteins; Regeneration; Transforming Growth Factor-B (TGF-B); Therapeutic Proteins; Tissue Engineering.

\section{Introduction}

Periodontitis is the most common inflammatory disease that af fects the supporting elements of the tooth, resulting in loss of attachment, loss of alveolar bone and ultimately leading to loss of tooth. There are several modalities of treatment for periodontitis to regenerate the lost periodontium which include root biomodification, Guided Tissue Regeneration (GTR), Bone grafts, Enamel Matrix Proteins (EMP), Growth Factors (GF) (Lin NH et al 2009). Growth factors have been used enormously in periodontal regeneration like platelet growth factors, insulin like growth factors, fibroblast growth factor, cementum derived growth factors, epidermal growth factors, transforming growth factors $\alpha$ and $\beta$, vascular endothelial growth factor, tumor necrosis factor; monocyte derived growth factor (Huang $\mathrm{YH}$ et al. 2008). However irrespective of the various treatment modalities periodontal regeneration remains the ultimate goal. Recently the role of BMPs in regeneration is being enlightened based on its unique property of osteoinduction. BMPs belong to the family of TGF- $\beta$. TGF- $\beta$ also includes cartilage derived morphogenetic proteins and growth differentiation factors, Bone Morphogenetic Proteins like molecules (Hallman M\& Thor A2008).

Urist in 1965 coined the term BMPs or Osteogenetic protein and discovered the seminal property of BMPs to induced bone forming cells. Wozney cloned the first recombinant BMPs and identified their biochemical and biological characteristics and aminoacid sequences (Selvig KA et al. 2002).

\section{Chemical structure: (Sakou T 1998, Gran- jeiro JM et al. 2005, Huang YH et al. 2008).}

BMPs are produced as large precursor molecules. Bmp structure has three parts.

- Hydrophobic leader sequence signal peptide.

- A large propeptide region

- A mature domain

Seven conserved cysteine residues constitute the large propeptide and mature domain region, which is the characteristic of TGF- $\beta$ Super family. Disulfide bonds connect the chains between the dimers of BMPs and this dimerization enables the induction of bone forming cells. Chains between the dimers are of two types. Intrachain and interchain. Six of the seven cysteine residues participate in the intrachain disulfide bonds, which forms a rigid cysteine knot molecular structure. Remaining seventh cysteine residue participates in the interchain disulfide bond.

\section{Source: (Lynch SE et al. 1996, Lee MB 1997, Subach S 1997, Sakou T 1998)}

The available sources of BMPs are;

1) Human or animal bone matrices.

2) Recombinant DNA Technology.

3) Direct site application of DNA encoding for the desired factor.

There are different types of BMPs based on their function they are represented in the following table: 
Table 1: Based On Its Function They Are Divided Into Following Types (Setti SR 2002).

\begin{tabular}{ll}
\hline Types of BMPs & FUNCTION \\
\hline BMP-2 & Osteoinductive, Osteoblast differentiation, apoptosis \\
BMP-3 (osteo- & Most abundant BMP in bone \\
genin) & Osteoinductive, lung \& eye development \\
BMP-4 & Chondrogenesis \\
BMP-5 & Osteoblast differentiation, Chondrogenesis \\
BMP-6 & Osteoinductive, development of kidney \& eye \\
BMP-7 (OP-1) & Osteoinductive \\
BMP-8 (OP-1) & Nervous system, hepatic reticuloendothelial system, \\
BMP-9 & hepatogenesis \\
BMP-10 & Cardiac development \\
BMP-11 & Neuronal tissues \\
BMP-12 & Induces tendon iliac tissue formation \\
BMP-13 & Induces tendon \& ligament like tissue formation. \\
BMP-14 & Chondrogenesis enhances tendon healing \& bone \\
BMP-15 & formation. \\
\end{tabular}

\subsection{The primary and classic source of BMPs is bone isolation and purification}

Bone pieces should be cleaned for any remnants of soft tissue and ground to a particle size of about $1 \mathrm{~mm}$. the ground particles are subjected to demineralization, defatting and freeze drying in a frozen state. Strong electrolytes like guanidine HCL is used to break the strong non-covalent forces of BMP which are bound to the matrix.

\subsection{The second source of BMP is through recombinant technology}

\subsection{The method is by genetic therapy}

It enables the direct delivery of a genetic growth factor to the site of interest to encode for certain desired factors. This novel method permits the local application of BMPs directly to the site.

\section{Mechanism of action}

\subsection{Induction of ectopic bone formation (Wozney JM 1989, Wozney JM 1995).}

Both ectopic and orthotopic bone is stimulated by BMPs. Osteogenic and chondrogenic activity is shown by rhBMP2, BMP4, BMP5, BMP7. Subcutaneous implantation of BMPs initiates a sequential developmental cascade of events for chondroosteogenesis.

\subsection{Matrix interaction}

BMPs which are present in the matrix around the invading capillaries bind with the perivascular mesenchymal cells undergo growth and differentiation to initate osteogenesis. In conjunction with growth factors BMPs have therapeutic effects, in the scope of ridge augmentation and replacement of lost alveolar bone, various studies have proven the synergistic effects of rhBMP2 and PDGF (Lynch SE et al. 1996, Lee MB 1997, Sakou T 1998).

\subsection{Role of BMP in fracture healing}

BMPs present in the bone matrix are secreted in the fracture gap, acts as a transcription factor to regulate the proliferation and differentiation of cells and initiate osteogenesis.

\subsection{Infection}

Fresh fractures and non-unions treated with BMPs reduces the rate of infection due to increased stability by the increased osteoinduction activity and local vascular supply (Termaat MF et al. 2005).

\subsection{Angiogenesis and odontogenesis}

BMPs have shown to induce both Angiogenesis and odontogenesis which are not interlinked in the bone formation. Many invivo experiments have demonstrated the role of BMPs in reparative dentinogenesis. On comparison between the teeth treated with collagen based carrier and BMPs directly exposed or partially amputated dog dental pulps. The reparative dentin formed is double in BMP treated teeth (Lynch SE et al. 1996, Toyono T et al. 1997, Granjeiro JM et al. 2005).

Three phases of osteoinduction are

- Chemotaxis.

- Mitogenesis.

- Differentiation

\section{Signalling mechanism}

Intracellular signals are mediated by smads which are proteins and regulate transcription of distinct BMP target genes. According to their role, they are (Hallman M \&Vukicevic S 2008).

- Receptor associated smads (R-Smads).

- Common mediated smads.

- Inhibitory Smads.

Receptors associated with the smads are two types transmembrane serine/threonine kinase receptors (BR I and BR II).Three type 1 receptors serve the BMP pathway: BMP type Ia, Ib and activin receptor type Ia.

Inhibitory smads are antagonists: Proteins which bind to BMPs and prevents interaction of BMPs with their receptors. They are Noggin and Chordin. They bind with BMP-2, BMP-4 and BMP-7 and inhibits signallings.

A part from these BMPs need carriers to reach the site of action, as they are soluble in extracellular fluid and phagocytosed within 10 days.

\subsection{Carriers}

They are (Bartold et al. 2006, Miyaji H et al. 2002, Lieberman JR et al. 2002).

Natural-e.g. collagen, hyaluronin, chitosan, gelatin.

Synthetic-e.g. polyethelene glycol, polyethelene oxide, matrix extracts

Non-resorbable-e.g. EPTFE, Ceramic, Titanium mesh.

Resorbable-e.g. Alpha hydroxyl acids,polyglycolic acids, poly lactic acid.

Commonly used carriers are collagenous materials, demineralized bone matrix and synthetic polymers

\section{Role of BMPs in Periodontal Regeneration}

Regeneration is reproduction or reconstitution of a lost or injured part. For BMPs introduction and application clinically it should be evaluated thoroughly for its biological potential, efficacy and safety. Animal models are used for the research in periodontal regeneration using BMPs, as recombinant technology (rhBMP-2) is available. Both intramembranous bone formation and cementum formations are enhanced by using rhBMP- 2 during periodontal wound healing. The factors that alter the results of BMPs include BMP dose, influence of root conditioning, and occlusal load release characteristics of the carrier as well as suitability of the model.

The main property of BMPs is to induce the differentiation of osteoblastic cells from the pluripotential cells. Among all the 
BMPs, BMP-2 is shown to be more concerned with this activity RhBMP-2 has been proved to initiate bone induction process through many histological studies. When rhBMP-2 carrier complex is implanted, mesenchymal cells which are undifferentiated infiltrate the periphery of matrix, to degrade the matrix and invade the vascular endothelium to differentiate into osteoblasts laying bony trabeculae. Later bony trabecula undergoes physiological remodeling (Jamil A 1985, Lynch SE et al. 1996, Sharon R et al. 2001, Kaynak D et al. 2005, Wikesjo UM et al. 2006).

\subsection{Evidence}

Sigurdsson et al. (1995) displayed extensive bone regeneration following surgical implantation of rhBMP-2 in periodontal defect sites. Giannobile et al. (1998) and Ripamonti U et al. (1999) reported that OP-1stimulate bone formation and exert multiple effects on bone homeostasis by acting as mitogen on undifferentiated mesenchymal cells and osteoblast precursors, inducing the expression of the osteoblasts phenotype and acts as chemoattract for mesenchymal cells and monocytes.

Exogenous applications of selected BMPs/Ops initiate cementogenesis and regulate the assembly of a functionally oriented periodontal ligament system by transforming specific stem cells, capable of differentiation, towards cementoblasts and osteoblasts. Periodontal studies using BMP-2 in rodents suggest that after complete healing of the defect, the new bmp-2 induced a cellular or cellular cementum formation with its connective tissue attachment is compatible with normal PDL homeostasis. Increasing the dose of BMPs increase the amount of cementum formation, which is largely cellular in nature regardless of whether it forms on dentine or existing cellular cementum. Cellular formation may be encouraged by BMPs ability to accelerate matrix deposition by cells derived from the osteoprogenitor cells (King GN \& Hughes FJ 1999, King GN \& Hughes FJ 2001, King GN \& CochranDL2002, WikesjoUME et al.2003, Bartoldet al. 2006,Ripamonti U \& Renton L 2006).

Studies performed on periodontal regeneration has focused attention on rhBMP-12.Wikesjo et al. (1994) evaluated rhBMP-12 for periodontal tissue regeneration, particularly periodontal ligament formation. RhBMP-12 and rhBMP-2 were implanted on absorbable collagen sponges in periodontal defects and the results were compared after 60 days of healing. Greater bone regeneration was observed in implants treated with rhBMP-2, but ankylosis was noted. Defects treated with rhBMP-12 showed less bone regeneration, but exhibited a functionally oriented periodontal ligament system inserting into newly formed cementum (Wikesjo UM et al .2004).

Given the unique action of BMPs on mineralized tissue formation, the obliteration of periodontal ligament space and ankylosis is a potential complication for the use of BMPs in periodontium. The causes of ankylosis may be due to

- Significant perturbation of the homeostatic mechanisms in the periodontium

- Systemic administration of certain drugs like biphosphonates which interferes with the mineralization process

- Where bone formation was accelerated without regeneration of PDL space.

- The development of ankylosis is associated with the coronal aspects near the CEJ.

Lee $J$ et al. (2010)had focused on finding relevant growth and differentiation factors, optimal dosages, and the best approaches for delivery to develop clinically meaningful therapies in patientcentered settings.

Ripamonti U\& Petit JC (2009)concluded that the pleiotropic activities of the BMPs/OPs are vast and include the induction of periodontal tissue regeneration.

Jung RE et al.(2009)done a study to evaluate the long-term outcome of implants placed in bone augmented with a xenogeneic bone substitute material and a collagen membrane with or without the addition of recombinant human bone morphogenetic protein-2 (rhBMP-2).

Wikesjo UM et al. (2009)focused review illustrates the unique biologic potential, the clinical relevance and perspectives of recombinant human BMP-2 (rhBMP-2) using a variety of carrier technologies to induce local bone formation and implant osseointegration for inlay and onlay indications.

Wikesjo UM et al. (2008) studied the ability of recombinant human BMP-2 (rhBMP-2) coated onto a titanium porous oxide implant surface to stimulate local bone formation including osseointegration and vertical augmentation of the alveolar ridge.

Some of the studies are presented in the Table no: 2

Significant advances in periodontal tissue regeneration may be expected if ongoing and future research is tailored to provide further mechanistic insights into the relevance of apparent redundancy and the structure-activity profile of the recombinant human osteogenic proteins.

\section{Conclusion}

Animal studies have shown that rhbmp-2 can induce the bone formation and also its physiologic remodeling when implanted in periodontal bone defects. Though histological studies have proved in preclinical studies, clinical studies have to be improved to know the dose related results, delivery technologies, and conditions for stimulation of bone growth which will bring about a new era in craniofacial reconstruction. The ability to induce bone in periodontal research as well as craniofacial research using Bone Morphogenetic Proteins is not far from the clinical reality.

Table 2:Some of the other Studies

\begin{tabular}{|c|c|c|c|}
\hline S:no & Authors & Study done & Result \\
\hline 1. & $\begin{array}{l}\text { Sigurdsson } \\
\text { TJ et al. } \\
(1995)\end{array}$ & $\begin{array}{l}\text { Evaluation of } \\
\text { bone and ce- } \\
\text { mentum regen- } \\
\text { eration follow- } \\
\text { ing periodontal } \\
\text { surgery using } \\
\text { rhBMP-2 in six } \\
\text { beagle dogs }\end{array}$ & $\begin{array}{l}\text { Bone and cementum regen- } \\
\text { eration was significantly } \\
\text { enhanced in rhBMP-2 treated } \\
\text { defects compared to control. }\end{array}$ \\
\hline 2. & $\begin{array}{l}\text { Informational } \\
\text { paper (1996) }\end{array}$ & $\begin{array}{l}\text { BMPs produce } \\
\text { multiple effects } \\
\text { on bone by } \\
\text { acting as }\end{array}$ & $\begin{array}{ll}\text { 1) } & \text { Mitogen } \\
\text { chemoattractants for } \\
\text { mesenchymal cells } \\
\text { and monocytes } \\
\text { 3) Inducing the expres- } \\
\text { sion of osteoblasts } \\
\text { precursor type }\end{array}$ \\
\hline 3. & $\begin{array}{l}\text { Takahashi D } \\
\text { et al. (2005) }\end{array}$ & $\begin{array}{l}\text { Slow decompo- } \\
\text { sition of a carri- } \\
\text { er substance } \\
\text { with rhBMP-2 } \\
\text { and occlusal } \\
\text { loading in class } \\
\text { III furcation } \\
\text { defects }\end{array}$ & $\begin{array}{l}\text { Formation and Resolution of } \\
\text { ankylosis }\end{array}$ \\
\hline 4. & $\begin{array}{l}\text { Yang L et al. } \\
(2010)\end{array}$ & $\begin{array}{l}\text { Gene delivery of } \\
\text { the two growth } \\
\text { factors to human } \\
\text { periodontal } \\
\text { ligament cells } \\
\text { (hPDLCs) on } \\
\text { cell proliferation } \\
\text { and differentia- } \\
\text { tion }\end{array}$ & $\begin{array}{l}\text { Combined delivery of BMP- } \\
7 \text { and IGF-1 genes synergisti- } \\
\text { cally enhanced differentia- } \\
\text { tion of hPDLCs. }\end{array}$ \\
\hline 5. & $\begin{array}{l}\text { Li YF et al. } \\
(2010)\end{array}$ & $\begin{array}{l}\text { Estimated the } \\
\text { potential effects } \\
\text { of hBMP-7 gene } \\
\text { transfected bone } \\
\text { marrow stromal } \\
\text { cells }\end{array}$ & $\begin{array}{l}\text { Provided a new way for } \\
\text { repairing the periodontal } \\
\text { defects }\end{array}$ \\
\hline
\end{tabular}




\section{References}

[1] Lin NH, Gronthos S\&Bartold PM. (2009) Stem cells and future periodontal regeneration. Periodontology 2000. 51, 239251.http://dx.doi.org/10.1111/j.1600-0757.2009.00303.x.

[2] Huang YH, Polimeni G, Qahash\&M, Wikesjo UM. (2008) Bone morphogenetic proteins and osseointegration: current knowledge - future $\begin{array}{llll}\text { possibilities. } & \text { Periodontology } 2000 . & 47,\end{array}$ 223.http://dx.doi.org/10.1111/i.1600-0757.2007.00240.x.

[3] Hallman M, Thor A. (2008) Bone substitutes and growth factors as an alternative/complement to autogenous bone for grafting in implant den$\begin{array}{llll}\text { tistry. } & \text { Periodontology } & 2000 . & 47,\end{array}$ 192.http://dx.doi.org/10.1111/j.1600-0757.2008.00251.x.

[4] Selvig KA, Sorensen RG, Wozney JM\&Wikesjo UM.(2002) Bone repair following recombinant human bone morphogenetic protein-2 stimulated periodontal regeneration. Journal of Periodontology 73, (9):10201029.http://dx.doi.org/10.1902/jop.2002.73.9.1020.

[5] Granjeiro JM, Oliveira RC, Bustos-Valenzuela JC, Sogayar MC\& Taga R. (2005)Bone morphogenetic proteins: from structure to clinical use.Brazilian Journal of Medical and Biological Research 38, (10):146373. http://dx.doi.org/10.1590/S0100-879X2005001000003.

[6] Sakou T. (1998) Bone Morphogenetic Proteins: From Basic Studies to Clinical ApproachesBone; 22(6), 591-603.

[7] Lee MB. (1997) Bone morphogenetic proteins: background and implications for oral reconstruction. A review.Journal of ClinicalPeriodontol-

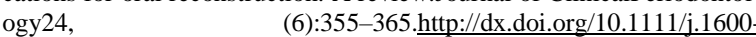
051X.1997.tb00198.x

[8] Sakou T. (1998) Bone Morphogenetic Proteins: From Basic Studies to Clinical ApproachesBone; 22(6), 591-603.

[9] Subach S. (1997) Bone Morphogenetic Proteins. Journal of Dental Research 12,123-126.

[10] Lynch SE, Genco RJ, Marx RE.(1996). Tissue engineering, Applications in Maxillofacial Surgery and Periodontics. Quintessence publishing, p. 25-75.

[11] Setti S. Rengachary, M.D. (2002) Bone Morphogenetic Proteins: Basic Concepts.Neurosurgical Focus 13(6), 6.http://dx.doi.org/10.3171/foc.2002.13.6.3.

[12] Wozney JM. (1995) the potential role of bone morphogenetic proteins in periodontal reconstruction. Journal of Periodontology 66(6), 506-510. http://dx.doi.org/10.1902/jop.1995.66.6.506.

[13] Wozney JM. (1989) Bone morphogenetic proteins. Progress in growth factor research 1, 267-280.http://dx.doi.org/10.1016/09552235(89)90015-X.

[14] Termaat MF, Den Boer FC, Bakker FC, Patka P, Haarman H(2005) Bone morphogenetic proteins development and clinical efficacy in the treatment of fractures and bone defects. Journal of Bone \& Joint Surgery.87(6): 1367-1378http://dx.doi.org/10.2106/JBJS.D.02585.

[15] Toyono T, Nakashima M, Kuhara S, Akamine A. (1997)Expression of TGF- Superfamily Receptors in Dental Pulp. Journal of Dental Research.76(9):15551560http://dx.doi.org/10.1177/00220345970760090701

[16] Vukicevic S, Sampath T (2008) Bone Morphogenetic Proteins: From local to systemic therapeutics. Birkhauser: Switzerland, p 1 6.http://dx.doi.org/10.1007/978-3-7643-8552-1.

[17] Bartold PM, Xiao Y, Lyngstaadas SP, Paine ML, Snead ML.(2006) Principles and applications of cell delivery systems for periodontal re$\begin{array}{llll}\text { generation. } & \text { 2000, } & \text { 41: } & \end{array}$ 135.http://dx.doi.org/10.1111/j.1600-0757.2006.00156.x.

[18] Miyaji H, Sugaya T, Miyamoto T, Kato K, Kato H. (2002) Hard tissue formation on dentin surfaces applied with recombinant human bone morphogenetic protein-2 in the connective tissue of the palate. Journal $\begin{array}{lll}\text { of Periodontal } & \text { Research, } & \text { 37(3):204 }\end{array}$ 209.http://dx.doi.org/10.1034/j.1600-0765.2002.01611.x.

[19] Lieberman JR, Daluiski A, Einhorn TA. (2002) the role of growth factors in the repair of Bone. Biology and clinical applications. Journal of Bone\& Joint Surgery, 84-A(6):1032-1044.

[20] Drs. Sharon R. Bannister, Chair and Douglas R. Dixon, Vice-ChairDrs. James B. Barnes, Frederick C. Bisch, Casey M. Campbell, Margaret Hill, Robert A. Faiella, Cristina Cunha Villar, and S. Jerome Zackin.(2001) Glossary of Periodontal terms (4th edition) American Academy of Periodontology.

[21] Wikesjo UM, Susin C, Qahash M, Polimeni G, Leknes KN, Shanaman RH, Prasad HS, Rohrer MD, Hall J. (2006) The critical-size supraalveolarperi-implant defect model: characteristics and use. Journal of Clinical Periodontology, 33(11):846-854.http://dx.doi.org/10.1111/j.1600051X.2006.00985.x

[22] Kaynak D, Meffert R, GunhanM,Gunhan O.(2005) A histopathologic investigation on effects of electrical stimulation on periodontal tissue regeneration in experimental bony defects in dogs. Journal of Periodontology, 2204.http://dx.doi.org/10.1902/jop.2005.76.12.2194
[23] Jamil A. (1985) Recombinant Human Bone Morphogenetic Protein-2 in Implant Surgery- Alveolar Ridge Augmentation. Journal of Dental Research, 11:324-329.

[24] Sigurdsson TJ, Lee MB, Kubota K, Turek TJ, Wozney JM, Wikesjo UM. (1995) periodontal repair in dogs: recombinant human bone morphogenetic protein-2 significantly enhances periodontal regeneration. Journal of Periodontology, 66(2); 131-138. http://dx.doi.org/10.1902/jop.1995.66.2.131.

[25] Giannobile WV, Ryan S, Shih MS, Su DL, Kaplan PL, Chan TC.(1998) Recombinant human osteogenic protein-1 stimulates periodontal wound healing in class III furcation defects. Journal of Periodontology, 69(2):129-137.http://dx.doi.org/10.1902/jop.1998.69.2.129.

[26] Ripamonti U, Helitosis M, Van den Heever B, Reddi AH. (1999) Bone morphogenetic proteins induce periodontal regeneration in baboon (Papioursinus). Journal of Periodontal Research; 29 (6):439445.http://dx.doi.org/10.1111/j.1600-0765.1994.tb01246.x.

[27] King GN, Cochran DL. (2002) Factors that modulate the effects of bone morphogenetic protein-induced periodontal regeneration: A Critical Review. Journal of Periodontology, 73(8):925936.http://dx.doi.org/10.1902/jop.2002.73.8.925.

[28] King GN, Hughes FJ. (2001) Bone morphogenetic protein-2 stimulates cell recruitment and cementogenesis during early wound healing. Journal of Clinical Periodontology, 28(5):465475.http://dx.doi.org/10.1034/j.1600-051x.2001.028005465.x.

[29] King GN, Hughes FJ. (1999) Effects of occlusal loading on ankylosis, bone, and cementum formation during bone morphogenetic protein-2Stimulated periodontal regeneration in vivo. Journal of Periodontology, 70(10):1125-1135.http://dx.doi.org/10.1902/jop.1999.70.10.1125.

[30] Ripamonti U, Renton L. (2006) Bonemorphogenetic proteins and the induction of periodontal tissue regeneration. Periodontology 2000 , 41:73-87.http://dx.doi.org/10.1111/i.1600-0757.2006.00155.x.

[31] Wikesjo UME, Xiropaidis AV, Thomson RC, Cook AD, Selvig KA, Hardwick WR. (2003) Periodontal repair in dogs: space providing ePTFE devices increase rhBMP-2 induced bone formation. Journal of Clinical Periodontology, 30(8):715-725.http://dx.doi.org/10.1034/j.1600051X.2003.00364.X.

[32] Wikesjo UM, Sorensen RG, Kinoshita A, Jian Li X, Wozney JM (2004) Journal of Clinical Periodontology, 31(8):66270.http://dx.doi.org/10.1111/j.1600-051X.2004.00541.x.

[33] Odajima T, Morita M, Kawanami M, Kato H.(2005) Journal of Periodontal Research, $40 \quad$ (4):299-305.http://dx.doi.org/10.1111/j.16000765.2005.00794.x.

[34] Position paper (1996). The potential role of growth and differentiation factors in periodontal regeneration. Journal of Periodontology, 67(5):545-553.

[35] Yang L, Zhang Y, Dong R, Peng L, Liu X, Wang Y, Cheng X. (2010) Effects of adenoviral-mediated co-expression of bone morphogenetic protein-7 and insulin-like growth factor-1 on human periodontal ligament cells. Journal of Periodontal Research, 45(4):532-40.

[36] Li YF, Yan FH, Zhong Q, Zhao X. (2010) Effect of hBMP-7 gene modified bone marrow stromal cells on periodontal tissue regeneration, Zhonghuayixuezazhi 25; 90(20):1427-30.

[37] Lee J, Stavropoulos A, Susin C, Wikesjo UM. (2010) periodontal regeneration: focus on growth and differentiation factors. Dental Clinics of North America., 54(1):93-111. http://dx.doi.org/10.1016/j.cden.2009.09.001.

[38] Ripamonti U, Petit JC. (2009) Bone morphogenetic proteins, cementogenesis, myoblastic stem cells and the induction of periodontal tissue regeneration. Cytokine \&Growth Factors Reviews, 20(5-6):48999.http://dx.doi.org/10.1016/j.cytogfr.2009.10.016.

[39] Jung RE, Windisch SI, Eggenschwiler AM, Thoma DS, Weber FE, Hammerle CH. (2009) a randomized-controlled clinical trial evaluating clinical and radiological outcomes after 3 and 5 years of dental implants placed in bone regenerated by means of GBR techniques with or without the addition of BMP-2. Clinical Oral Implants Research, 20(7):6606.http://dx.doi.org/10.1111/j.1600-0501.2008.01648.x.

[40] Wikesjo UM, Qahash M, Huang YH, Xiropaidis A, Polimeni G, Susin C. (2009) Bone morphogenetic proteins for periodontal and alveolar indications; biological observations - clinical implications Orthodontics and Craniofacial Research, 12(3):263 70.http://dx.doi.org/10.1111/j.1601-6343.2009.01461.x.

[41] Wikesjo UM, Qahash M, Polimeni G, Susin C, Shanaman RH, Rohrer MD, Wozney JM, Hall J. (2008) Alveolar ridge augmentation using implants coated with recombinant human bone morphogenetic protein-2 histologic observations. Journal of Clinical Periodontology, 35(11):1001-10.http://dx.doi.org/10.1111/j.1600-051X.2008.01321.x. 